\title{
Electrocatalytic hydrogen evolution by cobalt difluoroboryl-diglyoximate complexes $\dagger$
}

\author{
Xile Hu, Brandi M. Cossairt, Bruce S. Brunschwig, Nathan S. Lewis* and Jonas C. Peters* \\ Received (in Berkeley, CA, USA) 28th June 2005, Accepted 29th July 2005 \\ First published as an Advance Article on the web 23rd August 2005 \\ DOI: $10.1039 / b 509188 h$
}

In the presence of moderately strong acids in $\mathrm{CH}_{3} \mathrm{CN}$, cobalt complexes with $\mathrm{BF}_{2}$-bridged diglyoxime ligands are active catalysts for the reduction of protons to $\mathrm{H}_{2}$ at potentials as positive as $-0.28 \mathrm{~V}$ vs. SCE.

The search for transition metal complexes that are capable of catalyzing the reduction of protons to dihydrogen at low overpotentials presents an exciting challenge for coordination chemists. ${ }^{1}$ Much attention has been drawn to structural and functional models of the active sites of hydrogenases, especially the $\mathrm{H}$-clusters of the Fe-only hydrogenases, which feature dithiolatebridged, bimetallic iron cofactors that are rich in $\mathrm{CO}$ and $\mathrm{CN}^{-}$ auxiliary ligands. ${ }^{2,3}$ The Fe-only hydrogenases catalyze the reduction of protons to dihydrogen at the thermodynamic potential for $\mathrm{H}_{2}$ uptake/production $(c a$. $-0.41 \mathrm{~V} v s$. NHE at $\mathrm{pH}=7$ in water, or $c a .-0.65$ vs. SCE), ${ }^{4,5}$ whereas current biomimetic model compounds only catalyze hydrogen evolution at significantly more negative potentials (from $c a$. -1.1 to $-2 \mathrm{~V} v s$. SCE).$^{3,4,6}$ Transition metal complexes that are structurally distinct from the hydrogenase $\mathrm{H}$-cluster effect catalytic hydrogen evolution at comparable, and in some cases more positive, potentials than the biomimetic diiron model systems. Cobaltocene, ${ }^{7}$ $\left[\mathrm{CpCo}\left(\mathrm{PR}_{3}\right)_{2}\right]^{+8}$, metalloporphyrins, ${ }^{9}$ and certain macrocyclic complexes of cobalt ${ }^{10,11}$ and nickel, ${ }^{12}$ effect catalytic hydrogen evolution either in the presence of sacrificial chemical reductants or electrocatalytically.

A cobaloxime system, $\mathrm{Co}^{\mathrm{II}}\left(\mathrm{dmgBF}_{2}\right)_{2}\left(\mathrm{H}_{2} \mathrm{O}\right)_{2} \quad\left(\mathrm{dmgBF}_{2}=\right.$ (difluoroboryl)dimethylglyoxime), that catalyzes the reduction of protons to hydrogen by chromous ion in acidic aqueous solution was reported by Connolly and Espenson nearly two decades ago. ${ }^{11}$ Mechanistic studies suggested that in this system the ratedetermining step for proton reduction involved electron-transfer (ET) from $\mathrm{Cr}^{\mathrm{II}}$ to $\mathrm{Co}^{\mathrm{II}}$ via an inner-sphere ET pathway $\left(\mathrm{L}_{n} \mathrm{Cr}^{\mathrm{II}}\right.$ $\left.\mathrm{Cl}-\mathrm{Co}^{\mathrm{II}}\left(\mathrm{dmgBF}_{2}\right)_{2} \mathrm{~L}\right)$, followed by dissociation of the bridged species to generate a reactive $\mathrm{Co}(\mathrm{I})$ complex $\left[\mathrm{Co}^{\mathrm{I}}\left(\mathrm{dmgBF}_{2}\right)_{2} \mathrm{~L}\right]^{-}$ that is rapidly protonated to provide the hydride $\left[\mathrm{Co}^{\mathrm{III}}(\mathrm{H})\left(\mathrm{dmgBF}_{2}\right)_{2} \mathrm{~L}\right] .{ }^{11}$ The slightly unfavorable thermodynamics for the ET process were thought to be responsible for the slow overall rate of the catalysis. The $\mathrm{Co}\left(\mathrm{dmgBF}_{2}\right)_{2}$ system might therefore be well-suited to electrocatalytic hydrogen evolution because reduction of the parent $\mathrm{Co}$ (II) complex to the active $\mathrm{Co}$ (I) species by a solid-state electrode might be rapid, and the process

Division of Chemistry and Chemical Engineering, Arnold and Mabel Beckman Laboratories of Chemical Synthesis, California Institute of Technology, Pasadena, California 91125, USA.

E-mail: jpeters@caltech.edu; Fax: +1 6265774088; Tel: +1 6263954036

$\uparrow$ Electronic supplementary information (ESI) available: Complete experimental details. See http://dx.doi.org/10.1039/b509188h should occur at relatively positive potentials $\left(E^{\circ \prime}\left(\mathrm{Co}^{\mathrm{II} / \mathrm{I}}\right)=-0.55 \mathrm{~V}\right.$ vs. $\mathrm{SCE}$ in $\mathrm{CH}_{3} \mathrm{CN}$ ). Furthermore, modification of the diglyoxime ligand framework should allow modulation of the $\mathrm{Co}^{\mathrm{II} / \mathrm{I}}$ redox potential and hence the potential at which hydrogen evolution can occur. Although H-bridged cobaloximes degrade quickly in the presence of acids, ${ }^{11}$ the $\mathrm{BF}_{2}$-bridged cobaloxime complexes are substantially more acid-resistant (see ESI for acid stability of $\mathbf{1}$ and $2) \dagger$ These systems therefore comprised the initial focus of our efforts to develop complexes that electrocatalyze proton reduction at positive potentials.

Here we describe electrochemical studies of $\mathbf{1}$ and $\mathbf{2}$ (Scheme 1) in the presence of several acids and establish that both $\mathbf{1}$ and $\mathbf{2}$ serve as catalysts for the reduction of protons to dihydrogen at the independently measured $\mathrm{Co}^{\mathrm{II} / \mathrm{I}}$ reduction potentials of $\mathbf{1}$ and $\mathbf{2}$, respectively. Indeed, complex $\mathbf{2}$ mediates hydrogen evolution at $-0.28 \mathrm{~V}$ vs. SCE in $\mathrm{CH}_{3} \mathrm{CN}$, which to the best of our knowledge is the most positive potential that has been reported for catalytic hydrogen evolution by a well-defined synthetic catalyst system under comparable conditions. The study also suggests that hydrogen evolution catalysis has a strong dependence on acid strength and the nature of the coordinating counter ions present in the system. This dependence appears to be accountable for the different catalytic behaviour between $\mathbf{1}$ and the related complex, $\mathrm{Co}\left(\mathrm{dmgBF}_{2}\right)_{2}\left(\mathrm{H}_{2} \mathrm{O}\right)_{2}$. According to a very recent study published by Artero and coworkers while this manuscript was being prepared, ${ }^{13}$ no catalytic wave was observed by cyclic voltammetry for $\mathrm{Co}\left(\mathrm{dmgBF}_{2}\right)_{2}\left(\mathrm{H}_{2} \mathrm{O}\right)_{2}$ in DMF using $\mathrm{Et}_{3} \mathrm{NHCl}$ as the acid source $\left(\mathrm{p} K_{\mathrm{a}}=10.7\right.$ in $\left.\mathrm{DMF}\right)$. In fact, hydrogen evolution catalysis was observed by bulk electrolysis at a potential $350 \mathrm{mV}$ negative of the $\mathrm{Co}^{\mathrm{II} / \mathrm{I}}$ reduction potential for this system $(-0.9 \mathrm{~V}$ vs. $\mathrm{Ag} / \mathrm{AgCl}){ }^{13}$

Fig. 1a depicts the cyclic voltammetry of $\mathbf{1}$ at a glassy carbon electrode in an unstirred solution of $0.1 \mathrm{M}\left[{ }^{\mathrm{n}} \mathrm{Bu}_{4} \mathrm{~N}\right]\left[\mathrm{ClO}_{4}\right]$ in $\mathrm{CH}_{3} \mathrm{CN}$. In the absence of acid, a reversible one-electron reduction was observed at $-0.55 \mathrm{~V}$ vs. $\mathrm{SCE}$, corresponding to the $\mathrm{Co}^{\mathrm{II} / \mathrm{I}}$ redox couple. Upon addition of trifluoroacetic acid $\left(\mathrm{CF}_{3} \mathrm{COOH}\right.$, $\mathrm{p} K_{\mathrm{a}}=12.7$ in acetonitrile $\left.{ }^{14}\right)$, a catalytic wave appeared at a potential near $E^{\circ}$ for the $\mathrm{Co}^{\mathrm{II} / \mathrm{I}}$ couple of 1 (Fig. 1a). At low

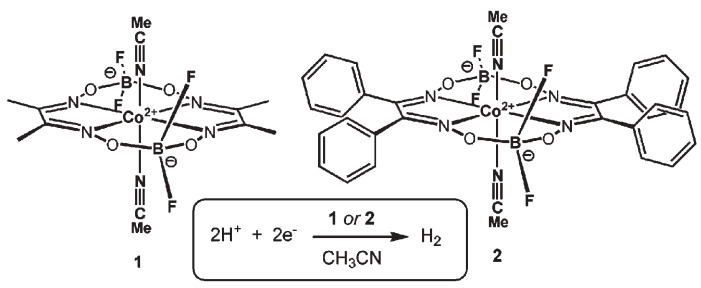

Scheme 1 Hydrogen-evolving catalysts 1 and 2. 

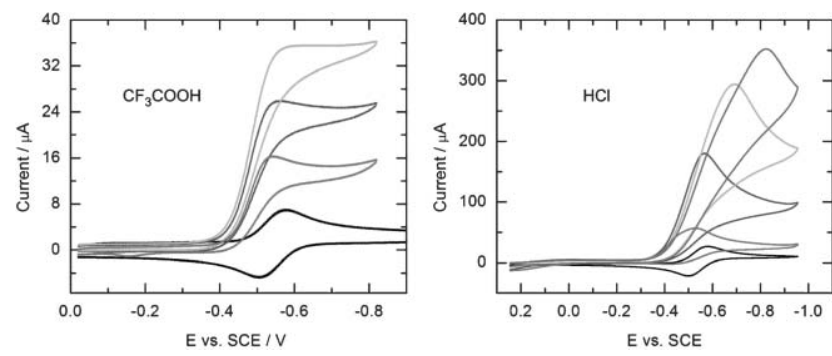

Fig. 1 Cyclic voltammogram of complex 1 in acetonitrile solution containing $0.1 \mathrm{M}\left[{ }^{\mathrm{n}} \mathrm{Bu}_{4} \mathrm{~N}\right]\left[\mathrm{ClO}_{4}\right]$ in the presence of acid: (a) (bottom-top) $0.34 \mathrm{mM} 1$ and no acid, $5 \mathrm{mM} \mathrm{CF}_{3} \mathrm{COOH}, 14 \mathrm{mM} \mathrm{CF}_{3} \mathrm{COOH}$, and $31 \mathrm{mM} \mathrm{CF} \mathrm{COOH}_{3}$; (b) (bottom-top) $1.5 \mathrm{mM} 1$ and no acid, $0.78 \mathrm{mM} \mathrm{HCl}, 3.1 \mathrm{mM} \mathrm{HCl}, 6.1 \mathrm{mM} \mathrm{HCl}$, and $9.2 \mathrm{mM} \mathrm{HCl}$. Scan rate: $100 \mathrm{mV} \mathrm{s}^{-1}$; glassy carbon electrode.

acid : catalyst concentration ratios (e.g., $5 \mathrm{mM} \mathrm{CF}_{3} \mathrm{COOH}$ and $0.34 \mathrm{mM} \mathrm{1}$ ), the catalytic wave exhibited a peak-like shape, indicative of an $\mathrm{E}_{\mathrm{r}} \mathrm{C}^{\prime}$ electrocatalytic process in which the catalytic reaction is sufficiently rapid that the current is controlled by diffusion of the substrate to the electrode surface. ${ }^{15,16}$ At higher acid : catalyst ratios, the potentials of the catalytic wave stayed nearly constant. The catalytic wave eventually approached a plateau shape $\left(31 \mathrm{mM} \mathrm{CF}_{3} \mathrm{COOH}\right.$ and $\left.0.34 \mathrm{mM} 1\right) .{ }^{16}$ An estimate of the overall catalytic rate constant is $770 \mathrm{M}^{-1} \mathrm{~s}^{-1} \cdot{ }^{4}$ Bulk electrolysis of a $0.5 \mathrm{mM}$ solution of 1 in the presence of $45 \mathrm{mM}$ $\mathrm{CF}_{3} \mathrm{COOH}$ in $100 \mathrm{~mL} \mathrm{CH}_{3} \mathrm{CN}$ at $-0.72 \mathrm{~V}$ consumed 96 coulombs of charge after 1 hour, corresponding to 20 turnovers per hour. Analysis of the gas mixture in the headspace of the electrolysis cell by gas chromatography confirmed the production of hydrogen gas with an almost quantitative Faradaic yield.

A similar result was obtained when $\mathrm{HBF}_{4} \cdot \mathrm{Et}_{2} \mathrm{O}\left(\mathrm{p} K_{\mathrm{a}}=0.1^{14}\right)$ was used as the acid source. $\dagger$ The catalytic rate constant was $c a$. $2 \times 10^{5} \mathrm{M}^{-1} \mathrm{~s}^{-1}$, but in this case the catalyst was relatively unstable. Spectroscopic measurements indicated that complex $\mathbf{1}$ decomposed gradually in $\mathrm{CH}_{3} \mathrm{CN}$ solutions that contained $\mathrm{HBF}_{4} \cdot \mathrm{Et}_{2} \mathrm{O}$. The degradation was first order with respect to the concentration of $\mathbf{1}$ and second order with respect to the acid concentration, with a rate constant of $8(1) \times 10^{2} \mathrm{M}^{-2} \mathrm{~s}^{-1}$. When the weaker benzoic acid $\left(\mathrm{p} K_{\mathrm{a}}=20.7\right)^{14}$ was used, no catalysis was observed.

Catalytic $\mathrm{H}_{2}$ evolution was also observed in the presence of $\mathrm{HCl}$, but the potential for chloride binding adds an additional variable to the analysis. Upon addition of $\mathrm{HCl} \cdot \mathrm{Et}_{2} \mathrm{O}\left(\mathrm{p} K_{\mathrm{a}}=8.9\right.$ for $\mathrm{HCl}$ in acetonitrile ${ }^{14}$ ), a catalytic wave appeared at a potential near $E^{\circ /}$ for the $\mathrm{Co}^{\mathrm{II/I}}$ couple of $\mathbf{1}$ (Fig. 1b). At low initial acid : catalyst ratios (e.g., $0.78 \mathrm{mM} \mathrm{HCl}$ and $1.5 \mathrm{mM} \mathrm{1}$ ), the catalytic current was observed at a potential slightly positive of $E^{\circ}\left(\mathrm{Co}^{\mathrm{II} / \mathrm{I}}\right)$, but as the acid concentration increased (e.g., $3.1 \mathrm{mM}$ $\mathrm{HCl}$ and $1.5 \mathrm{mM} \mathrm{1}$ ), the catalytic wave increased in amplitude and merged with the $\mathrm{Co}^{\mathrm{II} / \mathrm{I}}$ redox wave. Further increases of the concentration of the acid caused the peak of the catalytic wave to shift to more negative potentials, ultimately reaching $c a .-0.8 \mathrm{~V}$ $(9.2 \mathrm{mM} \mathrm{HCl}$ and $1.5 \mathrm{mM} \mathrm{1})$ and remaining at that position as further acid equivalents were added. The shape of the catalytic wave was indicative of diffusion-limited catalysis.

To probe the possibility that the negative shift of the catalytic wave at higher $\mathrm{HCl}$ concentrations might be caused by tight binding of $\mathrm{Cl}^{-}$to the pre-catalyst $\mathbf{1}$, the cyclic voltammetry of $\mathbf{1}$ was examined in the presence of added $\mathrm{Cl}^{-}$. With a 5-20 fold excess of $\left[{ }^{\mathrm{n}} \mathrm{Bu}_{4} \mathrm{~N}\right][\mathrm{Cl}]$, the cathodic peak of the $\mathrm{Co}^{\mathrm{II} / \mathrm{I}}$ redox couple for $\mathbf{1}$ split into two peaks, and transformed into a single peak, at ca. $-0.8 \mathrm{~V}$, when a much larger excess of $\left[{ }^{\mathrm{n}} \mathrm{Bu}_{4} \mathrm{~N}\right][\mathrm{Cl}]$ (>100 fold) was present. $\dagger$ These data are consistent with a modest association between $\mathrm{Cl}^{-}$and $\mathbf{1}$, generating the anionic species $\left[\mathrm{Co}\left(\mathrm{dmgBF}_{2}\right)_{2}\left(\mathrm{CH}_{3} \mathrm{CN}\right)(\mathrm{Cl})\right]^{-}\left(\mathbf{1} \cdot \mathrm{Cl}^{-}\right)$, which is expected to have a more negative reduction potential than $\mathbf{1}$ itself. With small amounts of $\mathrm{Cl}^{-}$, both 1 and $\mathbf{1} \cdot \mathrm{Cl}^{-}$are present, and thus give rise to two reduction peaks; at much higher $\mathrm{Cl}^{-}$concentrations, the $1 \cdot \mathrm{Cl}^{-}$species predominates, and hence one reduction peak is observed. The chloride binding constant was estimated from the electrochemical data to be $700 \mathrm{M}^{-2}$. $\uparrow$ The cathodic peak at $-0.8 \mathrm{~V}$ is presumed to correspond to the $\mathrm{Co}^{\mathrm{II} / \mathrm{I}}$ reduction process of the $1 \cdot \mathrm{Cl}^{-}$species.

$1 \cdot \mathrm{Cl}^{-}$is also an active electrocatalyst for hydrogen evolution, and a catalytic wave was observed to be coincident with $E^{\circ \prime}\left(\mathrm{Co}^{\mathrm{II} / \mathrm{I}}\right)$ when $\mathrm{HCl} \cdot \mathrm{Et}_{2} \mathrm{O}$ was added to an acetonitrile solution that contained $\mathbf{1} \cdot \mathrm{Cl}^{-}$(formed by the addition of $\left.\left[{ }^{n} \mathrm{Bu}_{4} \mathrm{~N}\right][\mathrm{Cl}]\right) \cdot \uparrow$ Hence the catalytic waves (Fig. 1b) at higher $\mathrm{HCl}$ concentrations are consistently ascribable to the superposition of the two individual catalytic waves for $\mathbf{1}$ and $\mathbf{1} \cdot \mathrm{Cl}^{-}$.

The diphenyl-derivative $\mathbf{2}$ was also prepared and studied to ascertain whether it was possible to tune the potential positively while still retaining a significant rate of $\mathrm{H}_{2}$ electrocatalysis. Substitution of the methyl groups on the diglyoxime backbone in $\mathbf{1}$ by less electron-releasing phenyl groups in $\mathbf{2}$ effects a positive shift of $c a .260 \mathrm{mV}$ for $E^{\circ \prime}\left(\mathrm{Co}^{\mathrm{II} / \mathrm{I}}\right)$. The cyclic voltammogram of $\mathbf{2}$ in the presence of $\mathrm{HCl} \cdot \mathrm{Et}_{2} \mathrm{O}$ in acetonitrile is shown in Fig. 2a. In the absence of acid, one reversible redox event was observed at $-0.28 \mathrm{~V}$, corresponding to the $\mathrm{Co}^{\mathrm{II} / \mathrm{I}}$ couple of $\mathbf{2}$. The addition of $\mathrm{HCl} \cdot \mathrm{Et}_{2} \mathrm{O}$ triggered the appearance of an electrocatalytic wave near this potential. The catalytic wave increased in amplitude as the acid concentration was increased, eventually plateauing at an initial acid : catalyst ratio of $c a .25: 1(12.2 \mathrm{mM} \mathrm{HCl}$ and $0.5 \mathrm{mM}$ 2). In contrast to the behavior observed for $\mathbf{1}$, the potential at which the catalytic wave occurred for $\mathbf{2}$ was nearly constant as the acid : catalyst ratio was varied. In the presence of ca. 100 equiv. [ $\left.{ }^{\mathrm{B}} \mathrm{Bu}{ }_{4} \mathrm{~N}\right][\mathrm{Cl}], 2$ did not generate $\mathrm{H}_{2}$, even at potentials as negative as $-1.0 \mathrm{~V}$. $\uparrow$ The electrochemical behavior thus suggests that for the specific case of 2 , chloride binding poisons $\mathrm{H}_{2}$ evolution catalysis. At modest $\mathrm{HCl}$ concentrations, a substantial amount of unbound, and hence catalytically active 2 , was still present and electrocatalysis was still observed. The overall catalytic
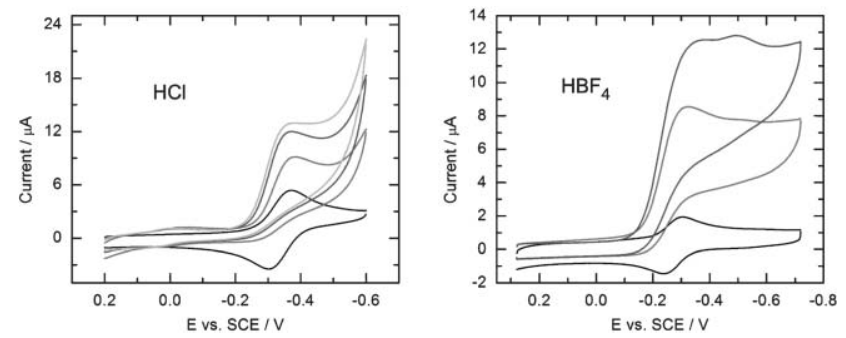

Fig. 2 Cyclic voltammogram of complex 2 in acetonitrile solution containing $0.1 \mathrm{M}\left[{ }^{\mathrm{n}} \mathrm{Bu}_{4} \mathrm{~N}\right]\left[\mathrm{ClO}_{4}\right]$ in the presence of acid: (a) (bottom-top) $0.5 \mathrm{mM} 2$ and no acid, $1.7 \mathrm{mM} \mathrm{HCl}, 7.0 \mathrm{mM} \mathrm{HCl}$, and $12.2 \mathrm{mM} \mathrm{HCl}$; (b) (bottom-top) $0.16 \mathrm{mM} 2$ and no acid, $0.25 \mathrm{mM} \mathrm{HBF}_{4}$, and $0.5 \mathrm{mM}$ $\mathrm{HBF}_{4}$. Scan rate: $100 \mathrm{mV} \mathrm{s}^{-1}$; glassy carbon electrode. 
rate constant for 2 using $\mathrm{HCl}$ was estimated to be $100 \mathrm{M}^{-1} \mathrm{~s}^{-1}$. Bulk electrolysis of a $0.38 \mathrm{mM}$ solution of $\mathbf{2}$ in the presence of $7.5 \mathrm{mM} \mathrm{HCl}$ in $100 \mathrm{~mL} \mathrm{CH}_{3} \mathrm{CN}$ at $-0.37 \mathrm{~V}$ consumed 41 coulombs of charge after one hour, corresponding to 11 turnovers per hour. Analysis of the gas mixture in the headspace of the electrolysis cell by gas chromatography confirmed the production of hydrogen gas with a Faradaic yield of $c a .90 \%$.

The rate of electrocatalysis by $\mathbf{2}$ was substantially increased by using the much stronger acid $\mathrm{HBF}_{4} \cdot \mathrm{Et}_{2} \mathrm{O}$. The cyclic voltammetry of 2 in the presence of $\mathrm{HBF}_{4} \cdot \mathrm{Et}_{2} \mathrm{O}$ is shown in Fig. $2 \mathrm{~b}$, and the catalytic rate constant was $c a .5 \times 10^{4} \mathrm{M}^{-1} \mathrm{~s}^{-1}$. Acetonitrile solutions of complex $\mathbf{2}$, however, were less stable in the presence of $\mathrm{HBF}_{4} \cdot \mathrm{Et}_{2} \mathrm{O}$ and competitively degraded with a rate constant of 35(1) $\mathrm{M}^{-2} \mathrm{~s}^{-1}$ (first order in 2, second order in $\mathrm{HBF}_{4}$ ). $\dagger$ No catalysis by $\mathbf{2}$ was observed when weaker acids, such as $\mathrm{CF}_{3} \mathrm{COOH}$ or benzoic acid, were used.

The foregoing observations demonstrate the ability of complexes 1 and $\mathbf{2}$ to catalyze electrochemical hydrogen evolution using a range of acids in acetonitrile. As expected for a system that involves protonation of at least one intermediate in the catalytic cycle prior to the rate determining step, the rate of catalysis depends on the strength of the acid. Because the catalytic waves occurred at potentials close to the independently measured values of $E^{\circ \prime}\left(\mathrm{Co}^{\mathrm{II} / \mathrm{I}}\right)$ for the various species of interest, the electrochemically generated $\mathrm{Co}$ (I) species are proposed to be the active species for catalysis, consistent with prior work on $\mathrm{Co}\left(\mathrm{dmgBF}_{2}\right)_{2} \mathrm{~L}_{2}$ in $\mathrm{H}_{2} \mathrm{O} .{ }^{11}$ The mechanism of the observed catalysis is likely to involve a $\mathrm{Co}^{\mathrm{III}}-\mathrm{H}$ hydride intermediate, formed by protonation of $\mathrm{Co}(\mathrm{I})^{-}$. Such a hydride might then undergo bimolecular hydrogen release, to regenerate the $\mathrm{Co}$ (II) catalyst species, or alternatively, undergo a second protonation to generate $\mathrm{H}_{2}$. The resulting $\mathrm{Co}$ (III) species would then be rapidly reduced to regenerate the $\mathrm{Co}$ (II) catalyst. Indeed, both of these pathways might be simultaneously operative. Further mechanistic studies are required to elucidate the relative contributions of these two alternatives.

Another interesting feature of the $\left[\mathrm{Co}\left(\mathrm{dmgBF}_{2}\right)_{2}\right]$ and $\left[\mathrm{Co}(\mathrm{dpgBF})_{2}\right]$ systems concerns their ability to mediate $\mathrm{H}_{2}$ evolution even under an atmosphere of CO. For example, acetonitrile solutions containing $\mathbf{1}$ or $\mathbf{2}$ that had been thoroughly sparged with $\mathrm{CO}$ still catalyzed $\mathrm{H}_{2}$ evolution at rates analogous to those described above (under comparable conditions). $\dagger$ The electrochemically or chemically generated $\mathrm{Co}(\mathrm{I})$ species ligated $\mathrm{CO}$ according to electrochemical and IR analysis, giving rise to their corresponding $\mathrm{Co}(\mathrm{I})$ monocarbonyl adducts (i.e., $\left\{\mathrm{Co}\left(\mathrm{dmgBF}_{2}\right)_{2}(\mathrm{CO})\right\}^{-}$and $\left.\left\{\mathrm{Co}\left(\mathrm{dpgBF}_{2}\right)_{2}(\mathrm{CO})\right\}^{-}\right)$. The addition of acid, however, caused rapid $\mathrm{CO}$ dissociation. This sequence was demonstrated chemically by preparing an authentic sample of $\left\{\mathrm{Co}\left(\mathrm{dmgBF}_{2}\right)_{2}(\mathrm{CO})\right\}\left\{\mathrm{CoCp}_{2}\right\} \quad\left(v(\mathrm{IR})=2013 \mathrm{~cm}^{-1} \mathrm{KBr}-\right.$ $\mathrm{CH}_{3} \mathrm{CN}$ ), produced by the addition of $\mathrm{CoCp}_{2}$ to an acetonitrile solution of $\mathbf{1}$ under an atmosphere of $\mathrm{CO}$. Upon the addition of $\mathrm{HCl}$ the $\mathrm{CO}$ band vanished rapidly. This is presumably because the $\left\{\mathrm{Co}^{\mathrm{I}}(\mathrm{CO})\right\}^{-}$is protonated to generate a Co(III) hydride, which would not be expected to be sufficiently backbonding to retain the $\mathrm{CO}$ ligand. Under this scenario, the overall rate of catalysis is not expected to change in the presence of $\mathrm{CO}$ as long as the protonation of the $\mathrm{Co}(\mathrm{I})$ carbonyl species and loss of $\mathrm{CO}$ is sufficiently fast, which appears to be the case at relatively high acid strength. Cyclic voltammograms of $\mathbf{1}$ and $\mathbf{2}$ in the presence of
$\mathrm{HCl} \cdot \mathrm{Et}_{2} \mathrm{O}$ recorded in $\mathrm{CO}$-saturated acetonitrile solutions support this view. $\dagger$

In summary, the potentials at which these $\left[\mathrm{Co}\left(\mathrm{dmgBF}_{2}\right)_{2}\right]$ and $\left[\mathrm{Co}\left(\mathrm{dpgBF}_{2}\right)_{2}\right]$ systems mediate $\mathrm{H}_{2}$ evolution $(-0.55$ and $-0.28 \mathrm{~V}$, respectively in acetonitrile) are significantly more positive than those of other molecular systems that catalyze $\mathrm{H}_{2}$ evolution, which typically require potentials in the range of $-1 \mathrm{~V}$ to $-2 \mathrm{~V}$ in organic solvents. ${ }^{3,4,6}$ Catalysis occurs in the presence of acids with modest (8.7-12.7) to low (0.1) $\mathrm{p} K_{\mathrm{a}}$ values in acetonitrile. Under analogous conditions but in the absence of added catalyst, analogous proton reduction was found to occur at a Pt electrode at $c a$. $-0.58 \mathrm{~V}$ with $\mathrm{CF}_{3} \mathrm{COOH}$ and $c a$. $-0.26 \mathrm{~V}$ with $\mathrm{HCl}$, with equilibrium potentials at $-0.12 \mathrm{~V}$ and $0.0 \mathrm{~V}$, respectively (see ESI). $\dagger$

For financial support we acknowledge the NSF through a Chemical Bonding Center (CBC). We also thank Prof. Alex Sessions for his generous help with the gas chromatography experiments.

\section{Notes and references}

1 U. Koelle, New J. Chem., 1992, 16, 157-169.

2 J. W. Peters, W. N. Lanzilotta, B. J. Lemon and L. C. Seefeldt, Science, 1998, 282, 1853-1858; M. Y. Darensbourg, E. J. Lyon, X. Zhao and I. P. Georgakaki, Proc. Natl. Acad. Sci. USA, 2003, 100, 3683-3688; M. Y. Darensbourg, E. J. Lyon and J. J. Smee, Coord. Chem. Rev., 2000, 206, 533-561; T. B. Rauchfuss, Inorg. Chem., 2004, 43, 14-26; D. J. Evans and C. J. Pickett, Chem. Soc. Rev., 2003, 32, 268-275.

3 C. Tard, X. M. Liu, S. K. Ibrahim, M. Bruschi, L. De Gioia, S. C. Davies, X. Yang, L. S. Wang, G. Sawers and C. J. Pickett, Nature, 2005, 433, 610-613.

4 A. J. Bard and L. R. Faulkner, in Electrochemical Methods: Fundamentals and Applications, John Wiley \& Sons, Inc., New York, 2nd edn, 2001.

5 R. H. Holm, P. Kennepohl and E. I. Solomon, Chem. Rev., 1996, 96, 2239-2314.

6 F. Gloaguen, J. D. Lawrence and T. B. Rauchfuss, J. Am. Chem. Soc., 2001, 123, 9476-9477; D. S. Chong, I. P. Georgakaki, R. MejiaRodriguez, J. Samabria-Chinchilla, M. P. Soriaga and M. Y. Darensbourg, Dalton Trans., 2003, 4158-4163; R. Mejia-Rodriguez, D. S. Chong, J. H. Reibenspies, M. P. Soriaga and M. Y. Darensbourg, J. Am. Chem. Soc, 2004, 126, 12004-12014; S. J. Borg, T. Behrsing, S. P. Best, M. Razavet, X. M. Liu and C. J. Pickett, J. Am. Chem. Soc., 2004, 126, 16988-16999; C. Tard, X. M. Liu, D. L. Hughes and C. J. Pickett, Chem. Commun., 2005, 133-135; S. Ott, M. Kritikos, B. Akermark, L. C. Sun and R. Lomoth, Angew. Chem., Int. Ed., 2004, 43, 1006-1009.

7 U. Koelle, P. P. Infelta and M. Gratzel, Inorg. Chem., 1988, 27, 879-883.

8 U. Koelle and S. Ohst, Inorg. Chem., 1986, 25, 2689-2694.

9 J. P. Collman, P. S. Wagenknecht and N. S. Lewis, J. Am. Chem. Soc., 1992, 114, 5665-5673; J. P. Collman, Y. Y. Ha, P. S. Wagenknecht, M. A. Lopez and R. Guilard, J. Am. Chem. Soc., 1993, 115, 9080-9088; I. Bhugun, D. Lexa and J. M. Saveant, J. Am. Chem. Soc., 1996, 118, 3982-3983; V. Grass, D. Lexa and J. M. Saveant, J. Am. Chem. Soc., 1997, 119, 7526-7532.

10 T. H. Chao and J. H. Espenson, J. Am. Chem. Soc., 1978, 100, 129-133.

11 P. Connolly and J. H. Espenson, Inorg. Chem., 1986, 25, 2684-2688.

12 J. P. Collin, A. Jouaiti and J. P. Sauvage, Inorg. Chem., 1988, 27, 1986-1990; T. L. James, L. S. Cai, M. C. Muetterties and R. H. Holm, Inorg. Chem., 1996, 35, 4148-4161.

13 M. Razavet, V. Artero and M. Fontecave, Inorg. Chem., 2005, 44, 4786-4795.

14 All $\mathrm{p} K_{\mathrm{a}}$ values cited in this paper were measured in acetonitrile: I. Kosuke, in Acid-Base Dissociation Constants in Dipolar Aprotic Solvents, Blackwell Scientific Publications, Oxford, 1990.

15 C. P. Andrieux, C. Blocman, J. M. Dumasbouchiat, F. Mhalla and J. M. Saveant, J. Electroanal. Chem., 1980, 113, 19-40.

16 J. M. Saveant and K. B. Su, J. Electroanal. Chem., 1984, 171, 341-349. 